\title{
THE POLITICAL MODEL OF SOCIETY \\ IN TERMS OF ITS VIRTUALIZATION: A PHILOSOPHICAL AND LEGAL ANALYSIS
}

\section{Okorokova V. V.}

\section{INTRODUCTION}

The rapid development and implementation of information technology is striking in its breadth of reach in modern human civilization. And it is not just about the place of the Internet as the main link between individuals, and between communities and the individual and society as a whole. Those new technologies that improve the process of human activity thus provide a whole set of tools, methods of study of society, both in historical perspective and in futuristic sense. Of course, the latter circumstance inevitably brings to the surface the study of virtualization, not only social but also political culture, which is the result of transformation processes of the present time.

We can already see today that the emergence of an information society is already gradually improving the political process of interaction between government and citizens, political decision-making, giving modern democratic regimes greater "openness" and accessibility to citizens, offering new forms of citizen participation. The theory and practice of the use of information and communication technologies in the realization of civic values, reforming and transformation of political institutions representing the state, social communities and individuals shows the specific nature of the adaptation of these technologies to political life, which is manifested both globally and nationally levels. These features of socio-political transformation suggest that we are witnessing the formation of a new channel of political communication, the dynamics of which can turn the idea of both the system of political 
activity and traditional instruments of political participation. In other words, it means changing the modern democratic paradigm into a more open one, which will promote the pluralism, new values, needs, methods and procedures.

As a consequence, in the context of the rapid development of the information society, discussions about the political order in the further process of transformation of society, as the sphere of human being, which is primarily affected by any fluctuations in society, intensify. As a notes I.A. Negodiyev the connection between informatization and politics is on the one hand, because political ideology and behavior pursued by certain social forces influence the pace, orientation and area of informatization. On the other hand, political life itself becomes the object of the information approach and this tendency of influence of informatics on political life is only growing ${ }^{1}$.

Therefore, it is not surprising that in our time it is increasingly possible to come across such concepts as "information policy" and "cyber politics", in turn E.G. Prylukova ${ }^{2}$ generally speaks of virtual political reality as a result of the impact of virtual reality on a person's social life. Of course, the subject of analysis in this case are the elements of the information process, which, on the one hand, determine the specific content of information, and on the other - allow to characterize the information space as a whole, as a political one. The rational use of information contributes to the creation of a certain political climate, the formation of mass consciousness, enables the manipulation of this consciousness, the creation of a system of political relations. Consequently, the interconnection of information processes and political

1 Негодаев И.А. Информатизация культуры. Социальный аспект информатизации. Ростов-на-Дону: Книга, 2003. URL: http://polbu.ru/negodaev_ informculture/ch05_i.html

${ }^{2}$ Прилукова Е.Г. Политический мир как виртуальная реальность. Вестник Южно-Уральского государственного университета. Серия: Социальногуманитарные науки. 2007. № 24 (96). С. 83. 
processes, the co-evolution of politics and informatics is becoming a natural trend in modern social development.

Exploring the problem of the above definitions, some modern scholars have identified the following elements of information policy, which by the way, in most of them approach cyber politics as well:

- a special type of knowledge that provides information in various mosaic configurations. The point is that, first, in the practice of activity in the emerging information space, information begins to be regarded as a raw material for knowledge production. Second, it is situational in the sense that it is initially applied only to a specific range of situations and is created for them. Thirdly, the new type of knowledge, by its nature, is temporary: it already creates a mechanism for its self-destruction. The difference, however, is that the classical scheme has a constant claim to generality, and this inertia gives rise to a whole host of problems described in the works on the theory and history of scientific revolutions. The latter circumstance defines the conditions for open communication and effective network partnership, which should be understood not as a good desire imposed on the basis of abstract moral imperatives, but as a condition for a full existence in the sphere of information policy.

- a special type of communication that specifies behaviors in the space of information flows and exchanges. The subject of political action in the information field is active and oriented towards a certain type of activity related to the processes of processing, interpreting and reconfiguring information. An active attitude to information, in turn, is a condition and basis for communication of a political entity with other such entities and, therefore, an actual presence in the political space. Its basic characteristic (from a policy point of view) will be the quality of interactivity, which involves the subject-subject relations of the participants of communication (and especially mass communication). 
- a special type of subjects (participants), forms the value and target structure of the information space. Information space changes the usual scale. This means that, due to the particular type of information (network) infrastructure, they are equated to the rights of other potential participants in the deposit. This leads to the fact that the individualization and "miniaturization" of the political entity in the information space is accompanied by a number of paradoxes, which include the transfer of the rules of privacy in public, by the very concept, space, space of publicity (information space) imposes its requirements to any private judgments and actions ${ }^{3}$.

Thus, according to the conditions of existence of such phenomenon as information policy according to S.E. Zueva is an interactive form of communication, especially its content, which can be interpreted as the production and reproduction of humanitarian knowledge, and as a special type of entity that accepts certain rules of interaction with other participants of communication ${ }^{4}$. Hence $\mathrm{V}$.Yu. Brovko formulates the definition of information policy - a set of purposeful communication and information actions that are intended to realize the interests of the subject of the communication process through mechanisms of influence on mass consciousness and behavior and include the collection, analysis, production and dissemination of information occasions and messages, as well as resource support information flows 5 .

It should also be noted that it complicates the study of this problem (which is at the same time an important component of its actualization in the scientific environment) and the fact that in modern

Зуев С.Е. Измерения информационного пространства (политики, технологии, возможности). URL: http://www.future.museum.ru/part01/010601.htm

${ }^{4}$ Ibid.

5 Бровко В.Ю. Концептуальные модели информационной политики: к вопросу систематизации. URL: https://cyberleninka.ru/article/n/kontseptualnyemodeli-informatsionnoy-politiki-k-voprosu-sistematizatsii 
philosophical and political science there are many concepts and theories that offer their alternative in response to the above questions. However, these studies are disparate in nature, depicting optimistic or pessimistic ways for political improvement in society and its consequences in the future. The only thing that unites them is the place of the Internet as the foundation of transients in the modern social environment, as a source of formation of a model of socio-political relations in a virtual society.

\section{The political model in a networked society}

Exploring the problem of the future political structure of the information society reveals many conceptual elements that cannot be ignored. From the outset, it is necessary to note the fundamental role of networks, on the basis of which the mechanism of the structure of society is revealed. According to O.V. Kurochkin nowadays transformation of political and administrative order goes from hierarchies (organization) to networks ${ }^{6}$. The content of this process is that society is no longer controlled solely by centralized structures, above all the state; control tools are scattered: material resources and information are shared among a variety of actors; the coordination of these actors is no longer the result of centralized management, but arises in the process of purposeful interaction of a large number of individual participants. The scientist emphasizes that nowadays the mechanism of political transformation has already acquired a deep meaning and a certain level that prevents it from changing its impulse in the process of building a perfect political model.

The fundamental importance of the problem of the network in the transformation of political relations in society is observed in the ideas of

${ }^{6}$ Курочкин А.В. Теория политических сетей: предпосылки становления и место в современной политической науке. Исторические, философские, политические и юридические науки, культурология и искусствоведение. Вопросы теории и практики. 2011. № 8 (14): в 4-х ч. Ч. III. URL: https://elibrary.ru/ item.asp?id=17074724 
A.V. Davydov, who emphasizes that in our time there is an inevitable process of formation of the so-called network policy ${ }^{7}$. The presence of direct equal ties between everyone and everyone, which is the defining quality of a network society, gives everyone who participates in them such an increase in capacity that cannot be abandoned. The reason for this is that a network society gives rise to the following circumstances:

- the need for management structures is sharply reduced, without which it was still impossible to organize the joint work of a large number of people. In conditions of low quality of communications such constructions were necessary, but now to transfer management influence is more favorable not on a chain consisting of officials, and with the help of Internet technologies;

- the social status of you who is involved in any matter ceases to be the prevailing circumstance that determines their behavior. Whatever position a person occupies in society, it imposes on him all kinds of formal restrictions, which, without regard to the merits of the case, are nevertheless capable of distorting its course;

- networked interaction dramatically increases the speed of resolution of almost any issue. Moreover, the costs of obtaining the necessary results do not increase, but are significantly reduced. In this way, the Network gives its participants a decisive advantage over the case managers, relying on a system of mediated relationships.

According to A.V. Davydov Network is more effective than the state, organizing interaction, and therefore the best guarantor of the already existing freedoms of the individual, while giving it new freedoms ${ }^{8}$. And such, when the deployment of which the state loses part

7 Давыдов А.В. О некоторых социально-политических последствиях становления сетевой структуры общества. Юбилейный аналитический вестник. АВСФ. 2004. № 13 (233). URL: https://guralyuk.livejournal.com/1897276.html

8 Давыдов А.В. О некоторых социально-политических последствиях становления сетевой структуры общества. Юбилейный аналитический вестник. AВСФ. 2004. № 13 (233). URL: https://guralyuk.livejournal.com/1897276.html 
of its present being. The network is a society of sovereign personalities, not a society of citizens. Moreover, there is always a form of action unknown to the Web for any action.

The idea of network policy shows how wide the field of research reveals put forward by $\mathrm{M}$. Castels ${ }^{9}$ the concept of a network society, because the formation of a society of this type presupposes a change in all spheres of human life at the core - the Network. Nowadays we can already see signs of transformation of socio-political relations on the basis of the Network. Drawing attention to the fundamental change in the role, functions and structure of the state as a result of the emergence of a network society M. Castels proposes the concept of "political network", whose research has led in our time to the emergence of political network theory, which considers the latter as a dominant model of governance in the information society. In his view, the new state of the information age is a new type of networking state, built on the network of political institutions and decision-making bodies of national, regional, local and local levels, the inevitable interaction of which transforms decision-making into endless negotiations between them. In turn, this inevitably contributes to the emergence of political networks that are designed to broaden the connection between citizens and the state, citizens and authorities.

According to L.V. Smorgunov political networks have four main functionalities:

1. instead of trying to reduce the complexity of society for effective governance, it involves increasing complexity as a necessary prerequisite for policy making and governance;

2. restores links between governance and politics;

${ }^{9}$ Кастельс М. Галактика Интернет: Размышления об Интернете, бизнесе и обществе. Екатеринбург: У-Фактория, 2004. URL: https://platona.net/load/ knigi_po_filosofii/sociologija/kastels_m_galaktika_internet_razmyshlenija_ob_internete_ biznese_i_obshhestve_2004/25-1-0-4711 
3. includes the moral dimension of the management and process of political decision-making;

4. it is not institutions but relationships and relationships that form the key point of consideration ${ }^{10}$.

If we look at these features in more detail, we can distinguish a number of characteristics that distinguish political networks from other forms of management activities in the field of public needs and interests:

- Networks are such a public affairs management structure that connects the state and civil society. This structure is empirically observable and theoretically described as a multitude of diverse public, private, public organizations and institutions that have some common interest;

- a political network is being formed to work out agreements in the process of exchanging the resources available to its actors. This means that there is a mutual interest of network participants in each other. Resources can be distributed unevenly, but regardless of the degree of their concentration and certain dominance of a number of network participants, the latter are forced to interact. There is a resource dependency between network participants;

- an important characteristic of a political network is a common cooperative interest. This is a sign has special significance, fragments distinguishes this regulatory system from the market, where each participant pursues primarily his own interests;

- from the point of view of developing political decisions, network participants do not line up in some hierarchy, where any organization has an advantage in terms of its power position. All participants in the network are equal in terms of the possibility of

10 Сморгунов Л.В. Сетевой подход к политике и управлению. Полис. Политические исследования. 2001. № 3. URL: https://www.politstudies.ru/index.php? page_id=453\&id=2901 
forming a joint decision on the issue of interest. Here, not vertical, but horizontal relations are observed;

- the network is a contractual structure consisting of a set of contracts arising on the basis of agreed formal and informal rules of communication. Political networks have a special culture of consensus. On the whole, the political network is a system of state and non-state entities in a certain sphere of politics, which interact with each other on the basis of resource dependence in order to reach a common agreement on the political issue of interest to all, using formal and informal norms ${ }^{11}$.

The above-mentioned features of political networks allow them to be defined as a set of relatively stable interrelationships by nature of non-hierarchical and interdependent, multifaceted actors who share common interests in politics and who share resources in order to promote those interests, recognizing that cooperation is the best way to achieve common goals.

In close connection with political networks, there is also a phenomenon such as the transformation of power. Interestingly, in the process of transformation of society, the political system loses power, and the latter does not disappear completely. In the information society, power remains embedded in cultural codes. Based on these codes, people and institutions make socio-political decisions. Power as an opportunity to prescribe behavior between individuals is contained in networks of information exchange and manipulation of symbols that correlate social actors, institutions and cultural movements through icons, representatives, intellectual amplifiers ${ }^{12}$.

11 Семенов В.А., Колесников В.Н. Политический анализ и прогнозирование. Учебное пособие. Стандарт третьего поколения. СПб.: Питер, 2014. C. 71.

12 Кастельс М. Галактика Интернет: Размышления об Интернете, бизнесе и обществе. Екатеринбург: У-Фактория, 2004. URL: https://platona.net/load/knigi_po_ filosofii/sociologija/kastels_m_galaktika_internet_razmyshlenija_ob_internete_biznese_i_ obshhestve_2004/25-1-0-4711 
In such circumstances, the new meaning is given the concept of "freedom", which is understood here primarily as space, and space is not physical, but the space of a multidimensional continuum, in which there are always several coordinate systems and one must define their parameters. The actor has the ability to choose which networks to participate in, which networks to form. In a network society, the individual becomes a key element in the complex configuration of networks. It acts as a kind of repeater of many communications. In other words, we are talking about the emergence in the conditions of a network society "public person", which is qualitatively different from the rational actor, maximizing their own profit, and obedient screw in the structure of the social system, whose sociality is determined by different subsystems of society.

\section{The problem of virtualization of political space}

The Internet is a means of political identification of society. By facilitating the task of mobilizing geographically, socially and professionally differentiated actors who have no connections in the real life other than the Internet, radically reducing organizational and information exposures, modern network communications really open up a new "virtual space" in the practice of organizational, party building self-organization of civil society ${ }^{13}$.

It is said that the virtualization of society contributes to the formation of virtual trends of parties and the image of politicians, propaganda virtual actions and virtual political and economic wars are underway. Virtual communications on the Internet are opening up a new "virtual dimension" in the practice of the political process. They are becoming such a political mechanism that is effective, cheap and efficient: mobilizes socially and professionally close people, sometimes

13 Туронок С.Г. Интернет и политический процесс. Общественные науки и современность. 2001. № 2. URL: https://istina.msu.ru/publications/article/6528987/ 
living long distances from each other; promotes party building; supports free discourse in civil society and much more. A phenomenon that clearly demonstrates the political role of the Internet is the technology of flash mobs - a civil action organized through the Internet, which involves the organization of masses of people within the metropolis. Hundreds or thousands of strangers before people meet at one of the squares or streets at once to show and express their views on a particular topic $^{14}$.

In the political sphere, virtual communities take on the character of political communities, which are understood as their separate type. Political communities are networks characterized by stable relationships, stable and highly restricted membership, vertical interdependence based on shared responsibility for service delivery, and isolation from other networks and public organizations (including parliament). Such networks are highly integrated and have a high degree of vertical interdependence and limited vertical coordination. It is emphasized that such networks concentrate on core functional interests (eg education or fire safety) ${ }^{15}$.

Virtual communities in the political sphere will increase the need to construct a new system of participation in the political process. As O. Bard and J. Zoderkvist point out, parliamentary elections can, of course, be conducted via the internet, when a citizen with the right to vote can simply enter his personal code into a computer and not go to the polling station, but then the very foundation of democracy will disappear - a wide debate in which all interested parties within the

14 Саяпин В.О. Технологии виртуализации политической власти в информационную эпоху. Исторические, философские, политические и юридические науки, культурология и искусствоведение. Bопросы теории и практики. 2015. № 8 (58): в 3-х ч. Ч. І. С. 160.

15 Сморгунов Л.В. Сетевой подход к политике и управлению. Полис. Политические исследования. 2001. № 3. URL: https://www.politstudies.ru/index.php? page_id $=453 \&$ id $=2901$ 
geographic area clarify positions on some issue ${ }^{16}$. On the network, everyone is looking for their own kind and creates together with them a new virtual space, free from conflicts within and about the geographical space.

Particular attention in this perspective deserves the idea of M.S. Vershinin, who proposes to consider the virtualization of the political sphere on the basis of the concept of "accelerated development of pluralism", based on two assumptions:

1) at the individual level, the Internet will not be able to change the fact that most people are extremely discerning about the choice of political issues and means of obtaining information. They show relatively strong interest in only a small number of political issues, remaining indifferent to everyone else;

2) information flow and exchange of information facilitates the involvement of the voters in the political process, as well as the organization and implementation by politicians, activists and other stakeholders of the process itself. In addition, broad access to information will accelerate the development of various political $\operatorname{processes}^{17}$.

In terms of this concept, the Internet facilitates the existing fragmentation of the current political system in accordance with the economic interests of political groups and the transition to a flexible system based on different strategies of influencing political groups less dependent on public institutions and organizations. M.S. Vershinin is inclined to believe that the Internet will have a serious impact on the political life of society, despite the fact that there are many reasons for

${ }^{16}$ Бард А., Зодерквист Я. NЕТОКРАТИЯ. Новая правящая элита и жизнь после капитализма. СПб.: Стокгольмская школа экономики в Санкт-Петербурге, 2004. URL: http://kob.su/kobbooks/net

17 Вершинин М.С. Политическая коммуникация в информационном обществе: перспективные направления исследований. «Актуальные проблемь теории коммуникации». Сборник научных трудов. СПб.: Изд-во СПб.: ГПУ, 2004. URL: http://www.russcomm.ru/rca_biblio/v/vershinin02.shtml 
theoretical and practical properties that make it doubtful that there is a direct link between changes in communication technology and political activity.

In this regard, among the main results of the active introduction of information and communication technologies in public life, especially in politics, are the changes in the categorical apparatus of modern political theory. Thus, in recent years, the socio-political lexicon has been enriched with the following concepts: "information democracy", "e-democracy", "modem democracy", "cyberdemocracy", "computermediated democracy", "digital democracy", "virtual democracy", "informational democracy", communication democracy", "e-citizenship", "cybernetic policy", "media democracy", "nanodemocracy" and others ${ }^{18}$. The only element that combines these concepts is the democratic system, provided that information technology dominates in society.

Exploring the problem of the future democratic order, S. Huntington makes two points that, in his opinion, explain the commitment of most countries of the modern world to a democratic order:

- firstly, democracy does not necessarily solve the problems of inequality, corruption, inefficiency, injustice and incompetent decision-making. But it provides institutional conditions to guarantee the freedom of the individual, to protect him from massive violations of human rights and violation of his human dignity. Democracy is a tool against tyranny, and as such it gives people a chance to solve other social problems;

- secondly, the spread of democracy in the world reduces the likelihood of wars between states. One of the fundamental facts of modern history is that since the establishment of modern democracy in the United States at the beginning of the 19th century wars between

18 Коритнікова Н.В. Напрями впливу інтернет-технологій на політичне життя суспільства. Украӥнський сочуіум. 2007. 2 (19). С. 141. 
democracies, with few exceptions, were not waged. There is an explanation for this. If this thesis is true, then as the number of democratic governments in the world grows, the ground for wars must narrow ${ }^{19}$.

In other words, democracy is more conducive to predicting the future political order as a form of political system, since, as S. Huntington noted, it proclaims freedom of the human factor in society. That is why it is not surprising why in our concepts we are talking about democracy with an emphasis on information and communication technologies, as a prefix "e-". This prefix not only does not deny the individual's right to freedom of expression, participation in the political process, etc., but is aimed at the complete elimination of some elements of hierarchical inequality in politics and obstacles to the free active participation of actors in solving topical political issues in a given society. In our case, this is a very important feature, since it opens the way to understanding the question of what form of political order modern creators of utopian projects hold and what factors influence it.

The forms of democratic system we have observed, as we have already seen, speak of a new type of democracy. N.N. Fedoseyeva examining existing models of information policy, both present and future, attributes modern democracy to democracy of the old form ${ }^{20}$. The rapid dissemination and implementation of new information and telecommunication technologies provides the public with new tools and methods that help "accelerate the transition from weak to true democracy", create wide opportunities for all members of society to more effectively manage their own lives as independent participants. As a result, process to lead to a change in the modern democratic paradigm

19 Хантингтон С. Будущее демократического процесса: от экспансии к консолидации. Мировая экономика и международные отношения. 1995. № 10. URL: http://www.umk.virmk.ru/study/U-DISCIPLINA/U-posob/Hfnington.htm

20 Федосеева Н.H. Демократия в информационном обществе. URL: http://center-bereg.ru/h1688.html 
into a more open one, which helps to establish pluralism, new values, needs, methods and procedures. The old form of democracy is no longer suitable for a society where a growing number of people can receive more and more information on various social and political issues through access to information and communication technologies and, through this new technology, form their own enlightened opinions on a wide range of issues.

In other words, it is a new political paradigm that is emerging and acquiring the character of a new type of discursive theory of democracy based on the study of information interactions in political space. This discourse implies a certain dialogue, an interactive immersion in political reality, a transcendence of virtuality, and is based on the functioning of information flows, the masses of knowledge in the context of increasing their volumes and the development of systems of global communication.

Each of the above-mentioned forms of democracy contains a certain social ideal that is in line with the interests of modern society in their future projection. In this regard, S.G. Turonok talking about the social ideal of the modern democratic system, first of all, the free competition of ideas in the socio-political market, which will lead to increased access of the population to interactive communications, dialogue between the authorities and individuals ${ }^{21}$. The essence of multilateral communication is that every individual who receives information through one channel or another, equally capable of participating in a full and identical context of public discussion, has the opportunity to listen and to be heard.

It is necessary to pay attention to the fact that among the abovementioned forms of democratic order in the conditions of widespread virtualization, "electronic democracy" and "information democracy"

21 Туронок С.Г. Интернет и политический процесс. Общзественные науки и современность. 2001. № 2. URL: https://istina.msu.ru/publications/article/6528987/ 
have become the most favorable variant of the further evolution of democracy in its best form. In a political context, e-democracy is understood as any democratic political system in which computers and computer networks are used to fulfill the essential functions of the democratic process, such as information dissemination and communication, citizens' interests and decision-making. From a communicative aspect, this concept is considered as a mechanism for providing political communication based on the application of networked computer technologies, which promotes the implementation of the principles of democracy and allows to adapt the political system to the real needs of the emerging information society ${ }^{22}$.

This concept of a new democracy incorporates all kinds of e-theories, ie it combines categories such as e-government, e-inequality, e-spying and others. As a result, the term e-democracy includes online human rights activities, electronic campaigning, and the use of network communication in political struggle. The key goal of e-democracy, as N.V. Koritnikova, is that it allows citizens to participate in the work of government bodies, and the state, in turn, more responsive to the needs of society ${ }^{23}$. The introduction of such projects contributes to the emergence of the Internet, as a space for the development and testing of socio-political strategies for social development with subsequent corrections in order to maximize the impact on the modernization of the social system.

Scholars identify the basic principles of e-democracy as follows:

- Accessibility - the solution to the problem of access to the activities of political institutions: for each person promptly disclosed

22 Грачов М.Н. «Электронная демократия» или «конец демократии»? Власть и политика: институциональные вызовы XXI века. Политическая наука: Ежегодник 2012. М.: Российская политическая энциклопедия (РОССПЭН), 2012. URL: http://grachev62.narod.ru/Grachev/grachev2012_4.html

23 Коритнікова Н.В. Напрями впливу інтернет-технологій на політичне життя суспільства. Украӥнський соџіум. 2007. 2 (19). С. 141. 
draft laws, analytical materials, current information. In spite of the fairly high degree of openness of traditional media, computer communications technologies are even more able to make government more transparent and accountable. The simplicity and unobtrusiveness of the information process now enables the personalized delivery of messages, paying attention to the characteristics of each group and providing information depending on the level of interest. Expected transparency, openness and accountability of official sources will increase public confidence in political institutions.

- Interactivity - providing continuous interactive, that is, continuous feedback. Reducing communication costs by several thousand times, network communications provide simultaneous and practical contact between an unlimited number of citizens without spacetime boundaries. Now no one depends on being close to the mass media to express their own point of view and defend their opinion. Through the Internet, everyone can address the messages that have been created to millions of people. Thanks to these characteristics, the Internet provides the potential for any participant in the political process to continuously communicate and gather like-minded people, as well as to be heard and involved in political issues at national and global levels.

- Partytsypator - the use of the latest information and communication technologies for the realization of civil rights, freedoms and interests, which is the basis of direct democracy. Partitioning allows for the inclusion in the process of political socialization of citizens who have different attitudes to politics, the activities of state power, because of personal reasons do not participate in solving political, economic and social problems. The main advantage will be that, most often, political partisanship will have a personal focus on achieving the goal in the interest of the social group represented by the individual.

- Consistency - a procedure for discussing topical issues, establishing a dialogue based on a high level of participants' awareness 
and developing an optimal view on political issues. Thanks to new opportunities to unite for "interests", directly and directly to defend their interests, the Institute of Lobbying - activity of social groups pursuing certain political and other goals - is significantly changing. The use of electronic discussion in lawmaking activities, the publication of proposals by the state to initiate a broad discussion among the population and the subsequent study of its results will lead to the emergence of a virtual mediator ${ }^{24}$.

Considering the principles of e-democracy, some scholars are inclined to believe that the essence of the decision-making process will be not only participatory, but also deliberative, which opens new horizons of policy implementation in any country in the system of international relations. ${ }^{25}$ Such a "strong" democracy requires strong dialogues between the state and civil society, between government and government. It is the latest information technologies that open up the prospects of national and local public policy reaching the citizens through the Internet, e-mail and public information booths, confirmed by certain western experiments with electronic voting, electronic voter manuals, citizen jury, etc. Drawing on these positions, the scientist emphasizes that "information democracy is an ideal hypothetical model of the political component of the future digital age, which is based on the values of information in combination with" socialized technologies of automation and communication. These technologies and communications mean free access for every citizen to any socio-political information using a political-information service; a real right and a real opportunity to enjoy all the benefits of both global and local society and

24 Коритнікова Н.В. Напрями впливу інтернет-технологій на політичне життя суспільства. Украӥнський соиіум. 2007. 2 (19). С. 142-143.

25 Ржевська Н.В. Вплив інформаційного суспільства на формування категоріального апарату політичної науки: інформаційна демократія як політична категорія. Вісник Львівського університету. Серія філос.-політолог. студіï. 2011. Випуск 1. С. 305. 
participate in important political decisions; the structure in which, through these technologies, the realization of the equality of all before the law and the mutual responsibility of the socio-political elements of the system are ensured. Most modern countries in the world are already in the process of forming this very type of democracy.

Information democracy is a multidimensional, multidimensional theoretical construction that determines the mental and technological shifts of modernity, global processes of improving the processes of production, processing, systematization and use of information and its masses, the formation of a global information and communication system of the world, the state, human being. Generated by technological progress and filled with deep social content, the category "information democracy" is an effective and optimal implementation of the latest information and communication tools in the political sphere on the basis of democratic ideals, values and norms as the most progressive social achievements of humanity.

\section{CONCLUSIONS}

Modern society is experiencing another stage of its transformation, which is mainly driven by computer technology. Informatization of society, and the virtualization that followed it, contributed to the change of the value-laden hierarchy of man and society as a whole, opened a new world, a new reality, different from the real everyday life. Of course, in such conditions, the sphere of political life gets a new impetus in its development, passing on the conditions and criteria of an information, or rather a virtual society. When we talk about a virtual person, this already implies a certain level of introduction of virtuality into social reality.

In this case, it can be noted that such a virtual / real ratio just facilitates the degree of the relationship between the political and social spheres, since it promotes the unification of citizens within a network society. Therefore, the paper draws attention to concepts such as 
electronic or digital democracy. Cyberspace is a medium for activating political activity, human awareness based on ongoing information in online environments.

Therefore, when talking about the modern political space, we should talk about virtual politics, the main components of which are egovernment, e-voting, online media, virtual political abatements, online forums and more. The main venue is a virtual space that captures the growing spheres of modern man's life.

\section{SUMMARY}

Thus, the philosophical and legal analysis of the problem of the impact of virtualization on the political sphere of society shows the following. First, it should be noted that the virtualization of society contributes to the expansion of civic participation in political life. Online broadcasts, video ads, online advertising, etc. promote the interest of the population in what is happening, and most importantly motivate them to participate directly in the Internet space.

Second, since virtual space is opposed to social reality, cyber politics becomes anonymous, which leads to boundless communication and, in general, relationships between the actors of this process in any case; contributes to the imitation of political activity on the Internet in the form of virtual states, gaming virtual communities and other forms.

Third, the virtualization of society contributes to the modeling of social reality. In this case we are talking about the formation of a model of political way of life, with an emphasis on future socio-political relations in a virtual society.

\section{REFERENCES}

1. Бард А., Зодерквист Я. NЕTОКРАТИЯ. Новая правящая элита и жизнь после капитализма. СПб.: Стокгольмская школа экономики в Санкт-Петербурге, 2004. 252 с. URL: http://kob.su/ kobbooks/net 
2. Бровко В.Ю. Концептуальные модели информационной политики: к вопросу систематизации. URL: https://cyberleninka.ru/ article/n/kontseptualnye-modeli-informatsionnoy-politiki-k-voprosu-siste matizatsii

3. Вершинин М.С. Политическая коммуникация в информационном обществе: перспективные направления исследований. «Актуальные проблемы теории коммуникациищ. Сборник научных трудов. СПб.: Изд-во СПб.: ГПУ, 2004. С. 98-107. URL: http://www.russcomm.ru/rca_biblio/v/vershinin02.shtml

4. Грачов М.Н. «Электронная демократия» или «конец демократии»? Власть и политика: институциональные вызовы XXI века. Политическая наука: Ежегодник 2012. М.: Российская политическая энциклопедия (РОССПЭН), 2012. С. 200-208. URL: http://grachev62.narod.ru/Grachev/grachev2012_4.html

5. Давыдов А.В. О некоторых социально-политических последствиях становления сетевой структуры общества. Юбилейный аналитический вестник. АВСФ. 2004. № 13 (233). URL: https://guralyuk.livejournal.com/1897276.html

6. Зуев С.Е. Измерения информационного пространства (политики, технологии, возможности).

URL: http://www.future.museum.ru/part01/010601.htm

7. Кастельс М. Галактика Интернет: Размышления об Интернете, бизнесе и обществе. Екатеринбург: У-Фактория, 2004. 328 c.

8. Коритнікова Н.В. Напрями впливу інтернет-технологій на політичне життя суспільства. Український соичіум. 2007. 2 (19). C. 139-148.

9. Курочкин А.В. Теория политических сетей: предпосылки становления и место в современной политической науке. Исторические, философские, политические и юридические науки, культурология и искусствоведение. Вопросы теории и практики. 
2011. № 8 (14): в 4-х ч. Ч. III. C. 117-120. URL: https://elibrary.ru/ item.asp?id=17074724

10.Негодаев И.А. Информатизация культуры. Социальный аспект информатизации. Ростов-на-Дону: Книга, 2003. URL: http://polbu.ru/negodaev_informculture/ch05_i.html

11.Прилукова Е.Г. Политический мир как виртуальная реальность. Вестник Южно-Уральского государственного университета. Серия: Социально-гуманитарные науки. 2007. № 24 (96). C. 83-88.

12.Ржевська Н.В. Вплив інформаційного суспільства на формування категоріального апарату політичної науки: інформаційна демократія як політична категорія. Вісник Львівського університету. Серія філос.-політолог. студії. 2011. Випуск 1. С. 303-310.

13.Саяпин В.О. Технологии виртуализации политической власти в информационную эпоху. Исторические, философские, политические $u$ юридические науки, культурология и искусствоведение. Вопросы теории и практики. 2015. № 8 (58): в 3-х ч. Ч. I. С. $159-166$ c.

14.Семенов В.А., Колесников В.Н. Политический анализ и прогнозирование. Учебное пособие. Стандарт третьего поколения. СПб.: Питер, 2014. 432 с.

15.Сморгунов Л.В. Сетевой подход к политике и управлению. Полис. Политические исследования. 2001. № 3. URL: https:// www.politstudies.ru/index.php?page_id=453\&id=2901

16.Туронок С.Г. Интернет и политический процесс. Общественные науки и современность. 2001. № 2. URL: https://istina.msu.ru/publications/article/6528987/

17.Федосеева Н.Н. Демократия в информационном обществе. URL: http://center-bereg.ru/h1688.html

18.Хантингтон С. Будущее демократического процесса: от экспансии к консолидации. Мировая экономика и международные 
отношения. 1995. № 10. URL: http://www.umk.virmk.ru/study/UDISCIPLINA/U-posob/Hfnington.htm

\section{Information about the author: Okorokova V. V.,}

Grand PhD, Associate Professor, Chair of World History and Methodology of Science, South Ukrainian National Pedagogical

University after K. D. Ushynsky 26, Staroportofrankivska str., Odesa, 65020, Ukraine 